\title{
ANALYSIS OF CADRE COMPLIANCE LEVELS IN RUNNING HEALTH PROTOCOLS IN THE ERA OF PANDEMIC COVID-19 IN PUSKESMAS LIMO DEPOK
}

\author{
Sri Wahyuningsih ${ }^{1 *}$, Hany Yusmaini ${ }^{1}$, Erna Harfiani $^{1}$, Meiskha Bahar $^{1}$ \\ ${ }^{1}$ Fakultas Kedokteran, Universitas Pembangunan Nasional Veteran Jakarta, DKI Jakarta, Indonesia \\ *Correspondence email: dr_sriwahyuningsih@yahoo.com
}

\begin{abstract}
The Covid-19 outbreak that originated in Wuhan's city is spreading very quickly and is currently a pandemic worldwide. Transmission through droplets that come out of the patient's nose or mouth, whether symptomatic or asymptomatic. The spark can enter directly or pass over the surface of surrounding objects. Efforts to prevent and fight COVID-19 must be carried out jointly with the community's cooperation and require strong discipline by washing hands frequently, maintaining distance, wearing masks, staying at home, and increasing body power. The purpose of this study was to determine the level of compliance of cadres in carrying out health protocols in the era of the Covid19 pandemic at Limo Health Center, Depok. This research method with a cross-sectional approach. The respondents were cadres of Limo Health Center, Depok. The sampling technique was total sampling. The research instrument used a questionnaire in the form of Google Form, and the data were analyzed using Chi-Square. The results showed that most of the respondents were included in the 4660 year interval (51.4\%) were highly educated / high school, tertiary education (70\%), knowledgeable $(54.3 \%)$, unemployed (87.1), obeyed the protocol. Health (50\%). Compliance increases in the elderly, higher education, sufficient knowledge, work status. In conclusion, there is no relationship between age $(\mathrm{p}=0.632)$, education level $(\mathrm{p}=0.794)$, knowledge level $(\mathrm{p}=0.253)$, work status $(\mathrm{p}=0.074)$ and compliance with the Covid-19 health protocol.
\end{abstract}

Keywords: Cadre Compliance Level; Covid-19; Health Protocol

\section{INTRODUCTION}

In late December 2019, the WHO China Country Office reported pneumonia of unknown etiology in Wuhan City, Hubei Province, China. In January, the pneumonia case was caused by SARS-CoV-2, and the disease was called COVID-19. The Covid-19 outbreak is increasing rapidly every day and spreading outside of China that the WHO declared a global pandemic. Currently, the whole world is experiencing a COVID-19 pandemic. ${ }^{1}$

As previously explained, COVID-19 is transmitted through droplets/splashes that come out of the nose or mouth of symptomatic or asymptomatic patients. At present, the spread of SARS-CoV-2 from human to human is the primary source of transmission, so that the spread has become more aggressive. ${ }^{1,2}$

The splash can enter directly through the mucosa of the eye, nose, mouth or contaminate the surface of objects around. People who touch contaminated objects and then touch their eyes, mouth, or nose will become infected with the virus. Therefore, preventive action by implementing health protocols is essential in suppressing the transmission of SARS-CoV-2 in the community.

The community has an essential role in breaking the chain of transmission of COVID19 to cause new sources of transmission / new clusters in places where people are moving, interacting, and gathering large numbers of people. The risk of people's movement and the 
gathering of people in public places and facilities has a large enough potential for COVID-19 transmission. The role of the community in being able to break the chain of transmission of COVID-19 (risk of infection and transmission). This must be done by implementing health protocols, namely washing hands frequently, covering mouth when coughing, maintaining a distance of 1-2 meters, wearing a mask when leaving the house, staying at home unless there is a need that requires leaving the house, maintaining endurance with balanced nutrition, sunbathing, exercising

People must make changes to their lifestyle with new arrangements and adaptations to their habits in order to live productively and avoid COVID-19 transmission. Discipline in applying the principles of a cleaner and healthier lifestyle is the key to suppressing the transmission of COVID-19, so it is hoped that this pandemic can end soon. ${ }^{1,3,4}$

Health cadres are part of the community expected to play an active role in helping solve various health problems, where at this time, cadres must be able to prevent the transmission of COVID-19. Cadres must provide accurate and correct information about the prevention of COVID-19 if needed. All the information must be obtained from the local Puskesmas and provide an excellent example for the surrounding community according to health protocols compliance. .,6,7 $^{5}$

\section{MATERIAL AND METHODS}

This type of research used a crosssectional design with 73 health cadres at Limo Health Center, Depok, taken by the total sampling technique. The data was collected through a questionnaire in the form of a Google Form that was distributed through the Cadres Group Whatsapp. Data were analyzed using Chi-Square.

\section{RESULT}

Table 1 below shows that most of the respondents are in the elderly category, but it is not much different from respondents with the adult age category. Respondents also have a high level of education, two times more than those with low education. Most of the respondents already have an adequate level of knowledge. Respondents are mostly not working, almost nine times more than those who work. The compliance level of cadres shows the same percentage of those compliant and non-compliant in implementing the Health protocol.

Table 1. Overview of the Percentage of Respondent Characteristics

\begin{tabular}{|c|c|c|}
\hline Variable & Number & Percentage \\
\hline \multicolumn{3}{|l|}{ Age } \\
\hline Adult & 34 & 48,6 \\
\hline Eldery & 36 & 51,4 \\
\hline \multicolumn{3}{|c|}{$\begin{array}{ll}\text { Level } & \text { of } \\
\text { education } & \end{array}$} \\
\hline High & 49 & 70,0 \\
\hline Low & 21 & 30,0 \\
\hline \multicolumn{3}{|l|}{$\begin{array}{l}\text { Knowledge } \\
\text { Level }\end{array}$} \\
\hline Good & 38 & 54,3 \\
\hline Enough & 20 & 28,6 \\
\hline Less & 12 & 17,1 \\
\hline \multicolumn{3}{|l|}{ Job Status } \\
\hline Working & 9 & 12,9 \\
\hline Not working & 61 & 87,1 \\
\hline \multicolumn{3}{|c|}{$\begin{array}{l}\text { Health Protocol } \\
\text { Compliance } \\
\text { Level }\end{array}$} \\
\hline Obedient & 35 & 50,0 \\
\hline Disobedient & 35 & 50,0 \\
\hline
\end{tabular}

Source: Primary Data, 2020

Table 2 below shows that most of the adult age respondents did not comply with the health protocol, while the elderly respondents were mostly obedient to implementing the health protocol but only a slight difference. The bivariate test results showed no relationship between age and the level of compliance with the COVID-19 health protocol.

Both respondents with higher education were mostly obedient to implementing health 
protocols, and respondents with low education were mostly non-compliant in implementing health protocols. The bivariate test results show no relationship between education level and the level of compliance with the COVID-19 Health protocol.

Respondents with an adequate level of knowledge were mostly non-compliant in implementing health protocols. Respondents with a sufficient level of knowledge mostly adhere to health protocols. Less knowledgeable respondents are as large as those who are obedient and non-compliant in implementing health protocols. The bivariate test results showed no relationship between the level of knowledge and compliance with the COVID-19 health protocol.

Working respondents mostly adhere to health protocols, and respondents who do not work mostly do not comply with health protocols. The bivariate test results showed no relationship between work status and the level of compliance with the COVID-19 health protocol.

Table 2. Relationship between Age, Education Level, Knowledge Level, and Work Status with COVID-19 Health Protocol Compliance Level

\begin{tabular}{|c|c|c|c|}
\hline \multicolumn{4}{|c|}{ Covid-19 Health Protocol Compliance Level } \\
\hline & & Obedient & $\begin{array}{l}\text { Dis- } \\
\text { obedient }\end{array}$ \\
\hline \multirow[t]{2}{*}{ Age } & Adult & 16 & 18 \\
\hline & Elderly & 19 & 17 \\
\hline \multirow{2}{*}{$\begin{array}{l}\text { Level of } \\
\text { education }\end{array}$} & High & 25 & 24 \\
\hline & Low & 10 & 11 \\
\hline \multirow{3}{*}{$\begin{array}{l}\text { Knowledge } \\
\text { level }\end{array}$} & Good & 16 & 22 \\
\hline & Enough & 13 & 7 \\
\hline & Less & 6 & 6 \\
\hline \multirow[t]{2}{*}{ Job-status } & Working & 7 & 2 \\
\hline & $\begin{array}{l}\text { Not } \\
\text { working }\end{array}$ & 28 & 33 \\
\hline
\end{tabular}

Table 3. Bivariate Selection

\begin{tabular}{lll}
\hline No & Variable & P-value \\
\hline 1 & Age & 0,632 \\
2 & Level of education & 0,794 \\
3 & Knowledge level & 0,253 \\
4 & Job status & 0,074 \\
\hline
\end{tabular}

\section{DISCUSSION}

Based on the study results, most cadres were categorized as older people aged 45 to $60(51.4 \%)$. Most of the respondents of adult age did not comply with the health protocol. This is inversely proportional to the cadres in the elderly category (46-60 years), mostly obeying the COVID-19 health protocol implementation. Age is one factor that affects a person's perceptive power and mindset. With increasing age, one's comprehension and mindset will be more developed. The range of adulthood is a mature age with good comprehension and mindset so that the knowledge possessed by someone with an adult age range will get better. Better knowledge will generate awareness that will be manifested through good behavior. The elderly have lower body resistance, so they are vulnerable to all kinds of diseases, including Covid-19.

The study results of patients who were confirmed with Covid-19 were mostly in the elderly, and the symptoms would be more severe in the elderly with comorbidities. The community already understands this, so they have a high awareness of taking care of the elderly and complying with health protocols for the elderly. ${ }^{1,8,9}$ However, from the data analysis results using Chi-square, the p-value was 0.631 , indicating that there was no relationship between age and the level of compliance with the COVID-19 health protocol.

In this study, there was no relationship between age and the level of adherence to the COVID-19 health protocol because there were almost the same proportions between the adult and elderly age groups who knew COVID-19 and the COVID-19 health 
protocol. Furthermore, influenced by the nonformal education, or personal experience, or community life. ${ }^{\mathbf{1 0}}$

Most of the cadres with a high level of education adhere to the COVID-19 health protocol. Most of them do not comply with the COVID-19 health protocol in communities with a low level of education. The level of education can affect the level of someone's knowledge. Knowledge will shape individual behavior. The higher the education taken, the easier the individual will receive various information. A person with higher education will have a broader knowledge and understanding in receiving information about COVID-19 and the COVID-19 health protocol. Correct understanding will lead to healthy attitudes and behaviors as expected. ${ }^{8,9}$ However, data analysis results using Chisquare obtained a p-value of 0.794 , which means that there is no relationship between the level of knowledge and the level of compliance with the COVID-19 health protocol. The absence of a relationship between the level of education and the level of adherence to the COVID-19 health protocol in this study could be due to changes in a person's behavior in adhering to the health protocol against COVID-19. The level of compliance does not always have to be in line with the formal education taken but can also be influenced by non-formal education or personal experience, or community life. ${ }^{10}$

More than half of the respondents have good knowledge, with a percentage of $54.3 \%$, with $28.6 \%$ having sufficient knowledge, and the rest having less knowledge. Respondents with good knowledge had a higher proportion of respondents who did not comply with the COVID-19 health protocol. Respondents with sufficient knowledge were mostly compliant with the Covid-19 health protocol. Knowledge is thoughts, ideas, ideas, concepts, and human understanding and is a domain that influences a person's behavior. ${ }^{8,9}$ The analysis results using chi-square showed a p-value of 0.253 so that there was no statistically significant relationship between knowledge and adherence to health protocols. The results showed no relationship between knowledge and behavior, which could be caused by other factors, such as the social cognitive theory put forward by Bandura. Social cognitive explains that behavior is influenced by personal factors and is also influenced by environmental factors. Environmental factors represent the influence of the situation and the environment in which behavior is carried out, so that good knowledge does not guarantee good behavior. 11

The majority of respondents do not work, with a percentage of $87.1 \%$. Respondents who work are more likely to adhere to health protocols, while respondents who do not work are more likely to not adhere to health protocols. The chi-square analysis results showed a p-value of 0.074 , which indicated no significant relationship between work status and health protocols. The lack of prevention and mitigation can cause this meaningless relationship and education at the workplace following the Minister of Health's Circular on the Prevention of Coronavirus Disease (COVID-19) Transmission Protocol. $^{12}$

The compliance of cadres in implementing health protocols shows that $50 \%$ of cadres obeyed the health protocol, and $50 \%$ had not complied with the health protocol. Three factors make someone behave disobediently, namely from psychological, socio-economic-cultural aspects, and government authority perceptions. Psychological aspects include ideology, expectations, religious coping, psychological well-being, knowledge and experience, awareness, and commitment to regulations. Social aspects include social awareness and acceptance, economic conditions, and collective culture. Aspects of government conditions include perception of and trust in authority, cooperation between institutions, and infrastructure support. ${ }^{13}$

As a result of the Covid-19 pandemic, it psychologically affects the community with regulations on implementing health protocols, limiting activities both in carrying out worship activities, going to school, traveling, and working. It has a tremendous impact on 
the economic sector, which can cause anxiety, depression, or suicide attempts because of decreased or even no income.

The resulting stress can lead to noncompliance with existing policies. Some of these things make it difficult for individuals to follow the suggestions and rules set by policymakers. People feel bored and uncomfortable if they just stand by and desire to feel a normal life, which encourages disobedience. ${ }^{14}$ Therefore, public compliance with government policies cannot be applied evenly and comprehensively to various news media reports about security officers' reaction to keep residents at home and enforce Health protocols. The COVID-19 pandemic also had a positive impact because of the large amount of time with family and self-actualization in daily life activities. The level of expectation can also influence compliance. The community needs a high level of expectation to have self-confidence in response to social realities, which generally experience obstacles in the changes that occur due to systemic improvements in the future. ${ }^{13}$

\section{CONCLUSION}

a. Most of the respondents were in 46-60 year intervals

b. Most of the respondents have high education (Senior High School, University)

c. Most of the respondents are well-informed.

d. Most of the respondents did not work

e. The percentage of respondents who adhere to health protocols is only $50 \%$, the same as those who do not comply with health protocols

f. There was no relationship between age, education level, level of knowledge, employment status, and compliance with the COVID-19 health protocol

\section{REFERENCES}

1. Kementerian $\begin{aligned} & \text { Kesehatan } \\ & \text { Indonesia. } \\ & \text { Puskesmas. 2020. }\end{aligned}$
$\begin{aligned} & \text { Pepunjuk } \\ & \text { Pelayanan }\end{aligned}$

2. Susilo A, Rumende CM, Pitoyo CW,
Santoso WD, Yulianti M, Herikurniawan $\mathrm{H}$, et al. Coronavirus Disease 2019: Tinjauan Literatur Terkini. J Penyakit Dalam Indones. 2020;7(1):45.

3. Kementerian Kesehatan Republik Indonesia; Gerakan Masyarakat Hidup Sehat. Apa Yang Harus Dilakukan Masyarakat Untuk Cegah Penularan Covid-19. 2020. 2020;1-24.

4. Riskesdas K. Corona virus disease 2019. Peratur Menteri Kesehat Republik Indones [Internet]. 2020;Nomor 9(Pedoman Pembatasan Sosial Berskala Besar dalam Rangka Percepatan Penanganan Corona Virus DIsease 2019 (COVID-19)):2-6. Available from: http://jurnalrespirologi.org/index.php/jri/ article/view/101

5. Rl K. Kementrian Kesehatan RI, 2011, Pedoman Umum Pengelolaan Posyandu, Jakarta. 2011. 1-100 p.

6. Kementerian Kesehatan Direktorat Promosi Kesehatan dan Pemberdayaan Masyarakat. Koordinasi Kegiatan Promosi Kesehatan Masyarakat dan Pemberdayaan Masyarakat Pusat serta Daerah dalam Pencegahan COVID-19 [Internet]. 2020. Available from: https://promkes.kemkes.go.id/koordinasi -kegiatan-promosi-kesehatanmasyarakat-dan-pemberdayaanmasyarakat-pusat-serta-daerah-dalampencegahan-covid-19

7. Suhat, Hasanah R. Factors related to the activity of cadres in integrated health care sessions (study in Palasari health care district of Subang). Kesehat Masy. 2014;10(1):73-9.

8. Notoatmodjo S. Ilmu Perilaku Kesehatan. Jakarta: PT RIneka Cipta.; 2010.

9. Notoatmodjo S. Promosi Kesehatan dan Perilaku Kesehatan. Jakarta: PT Rineka Cipta; 2012.

10. Wulandari A, Rahman F, Pujianti N, Sari AR, Laily N, Anggraini L, et al. Hubungan Karakteristik Individu dengan Pengetahuan tentang Pencegahan Coronavirus Disease 2019 pada Masyarakat di Kalimantan Selatan. J Kesehat Masy Indones. 2020;15(1):42. 
11. Hapsari AI, Gunardi H. Hubungan Pengetahuan dan Sikap dengan Perilaku Orangtua tentang Diare pada Balita di RSCM Kiara. Sari Pediatr. 2018;19(6):316.

12. Kementrian Kesehatan RI. Panduan Pelayanan Kesehatan Balita Pada Masa Pandemi Covid-19. Kementeri Kesehat RI. 2020;1-30.

13. Abdul AR, Nuraini A, Elisa K, Iman S. Faktor-Faktor Psikososial dari Ketidakpatuhan Masyarakat pada Masa Pandemik. Artikel. 2020;19:1-10.

14. Steens A, De Blasio BF, Veneti L, Gimma A, Edmunds WJ, Van Zandvoort $\mathrm{K}$, et al. Poor self-reported adherence to COVID-19-related quarantine/isolation requests, Norway, April to July 2020. Eurosurveillance [Internet]. 2020;25(37):1-6. Available from: http://dx.doi.org/10.2807/15607917.ES.2020.25.37.2001607 